\section{ДОСЛІДЖЕННЯ СУЧАСНИХ ТЕНДЕНЦІЙ НА СВІТОВОМУ РИНКУ ЗЛИТТЯ}

\section{RESEARCH OF MODERN TENDENCIES IN THE GLOBAL MERGER MARKET}

\author{
БАЛУЄВА О. В., \\ доктор економічних наук, \\ професор, проректор з наукової \\ роботи, \\ ЧУПРИНА О. О., \\ доктор економічних наук, доцент, \\ професор кафедри маркетингу, \\ Донецький державний університет \\ управління, \\ ЗЕМЛЯНСЬКА Н. В., \\ кандидат наук з державного \\ управління, доцент кафедри \\ гуманітарних дисциплін, \\ Київська муніципальна академія \\ естрадного та циркового \\ мистецтв
}

\author{
BALUEVA O., \\ Doctor of Science in Economics, \\ Full Professor, Vice-Rector for \\ Research, \\ CHUPRINA O., \\ Doctor of Science in Economics, \\ Associate Professor, Professor of \\ the Department of Marketing, \\ Donetsk State University of \\ Management, \\ ZEMLIANSKA N., \\ PhD in Public Administration, \\ Associate Professor of the \\ Department of Humanities, \\ Kyiv Municipal Academy Of Circus \\ And Performing Arts
}

Визначено роль інтеграційних угод в міжнародному бізнесі. Проаналізовано сучасні тенденції, які панують на світовому ринку злиття. Розглянуто зміст горизонтальних та вертикальних ефектів, які можуть виникати в процесі реалізації угод про злиття. Досліджено досвід розвинених країн в сфері розвитку добросовісної конкуренції та недопущення надмірної концентрації ринків, який представляє інтерес для України.

Ключові слова: злиття; економічна конкуренція; світові ринки; концентрація; вертикальні та горизонтальні ефекти.

Определена роль интеграционных соглашений в международном бизнесе. Проанализированы современные тенденции на мировом рынке слияний. Рассмотрено содержание горизонтальных и вертикальных эффектов, возникающих в процессе реализации соглашений о слиянии. Исследован опыт развитых стран в сфере развития добросовестной конкуренции и недопущения чрезмерной концентрации рынков, представляющий интерес для Украины.

Ключевые слова: слияния; экономическая конкуренция; мировые рынки; концентрация; вертикальные и горизонтальные эффекты.

The role of integration agreements in international business is determined. The modern tendencies prevailing in the world merger market are analyzed. The content of horizontal and vertical effects that may arise in the process of implementing merger agreements is considered. The experience of developed countries in the field of development of fair competition and prevention of excessive concentration of markets, which is of interest to Ukraine, is studied.

Keywords: merger; economic competition; world markets; concentration; vertical and horizontal effects.

Постановка проблеми. Глобалізаційні процеси, які характерні для сучасної світової економіки, змінюють ринкові відносини, посилюючи міжнародну конкуренцію між провідними компаніями розвинутих країн, 
що, в свою чергу, впливає на збільшення кількості угод злиття, обумовлює їх мотиви та особливості.

Констатуємо, що інтеграційні угоди завжди мають дуальний характер, виступаючи, з одного боку, дієвим механізмом розвитку міжнародного бізнесу, а з іншого - призводячи до монополізації на відповідних ринках.

Серед позитивних ефектів як для компаній, що об'єднуються, так і для ринку загалом слід відзначити такі: економія від масштабу; налагодження стійких господарських зв'язків; можливість контролю ресурсів; зниження трансакційних витрат; стимулювання інноваційних технологій; збільшення доданої вартості кінцевого продукту тощо.

Разом з тим, злиття здатні спричинити і негативні наслідки, пов'язані зі зниженням, або, навіть, усуненням конкуренції на ринку та збільшенням рівня економічної концентрації.

Слід зазначити, що суперечливий характер та масштабність цих процесів потребують формування дієвої системи державного регулювання таких угод, адекватної сучасним економічним реаліям.

Констатуємо, що розвинені країни приділяють значну увагу розвитку добросовісної конкуренції та недопущенню надмірної концентрації ринків, здійснюючи жорсткий контроль за такими операціями.

Дослідники [1;2] справедливо визначають, що в рамках сучасної конкурентної політики в державах сформовано комплекси національних правил, дотримання яких забезпечує суб'єктам господарювання перспективи долучитися до нових можливостей, збільшити ринкову частку, скоротити витрати і вдосконалити бізнеспроцеси на паритетних умовах.

Звертаючи увагу на той факт, що Україна виступає одним 3 учасників світових процесів злиття, а інвестиції у вітчизняні підприємства $€$ рушійною силою розвитку економіки, проблема дослідження основних тенденцій на відповідних ринках та досвіду розвинених країн в сфері захисту конкуренції та недопущення надмірної концентрації в результаті таких угод, $\epsilon$ надзвичайно актуальним для країни.

Аналіз останніх досліджень і публікацій. Особливості процесів злиття досліджуються в працях таких вчених, як: Т. Гамма [3], Г. Єгорова [4], Дж. Кенгельбах (J. Kengelbach) та К. Касерер (C. Kaserer) [5], А. Мелещенко [6], Л. Побоченко [7], І. Пучко [8], В. Сабадаш [9], Г. Стахєєва [10], Дж. Фаррелл (J. Farrell) [2], Ю. Цимбал [6] та інших.

Значну увагу проблемам, пов'язаним 3 такими угодами, приділено в документах національних регулюючих органів країн світу, наприклад, Федеральної торгової комісії (США) [11; 12]; спільних інституцій із регулювання Європейького Союзу (ЄC), зокрема Європейської комісії [13] тощо.

Питання регулювання відносин, контролю за концентраціями, захисту економічної конкуренції в процесі злиття компаній знаходяться в полі зору Антимонопольного комітету України [14; 15].

Однак, в сучасних умовах поширення глобалізаційних та інтеграційних процесів, постійних змін зовнішніх впливів, дослідження світових тенденцій на ринку злиття та пов'язаних з цим питань потребують більш глибокого наукового вивчення. Це сприятиме своєчасному вирішенню проблем, пов'язаних 3 економічною 
концентрацією, сприятиме попередженню або мінімізації негативних ефектів, викликаних угодами злиття.

Метою статті є дослідження сучасних тенденцій, які панують на світовому ринку злиття та досвіду розвинених країн в сфері захисту економічної конкуренції внаслідок таких угод.

Виклад основного матеріалу дослідження. Починаючи 32000 року, у всьому світі було оголошено понад 790 тис. угод злиття (на більш ніж 57 трлн дол. США). Але, сягнув свого максимуму за останні два десятиріччя, починаючи з 2017 року, їх кількість почала знижуватись. І за результатами 2020 року зменшилася до 45652 транзакцій (на 7,5\%) (рис. 1).

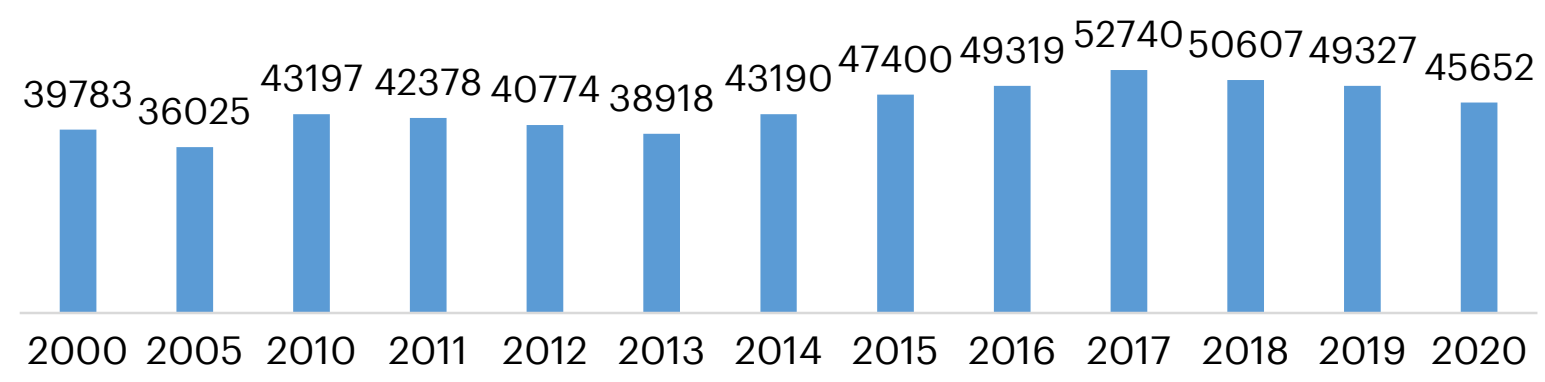

Рис. 1. Кількість угод злиття у світі, одиниць

Джерело: побудовано авторами за матеріалами [16; 17]

Разом з цим спостерігалось і падіння вартості таких угод до 2835 трлн дол. (на 15,9\% в порівнянні з 2019 роком) (рис. 2).

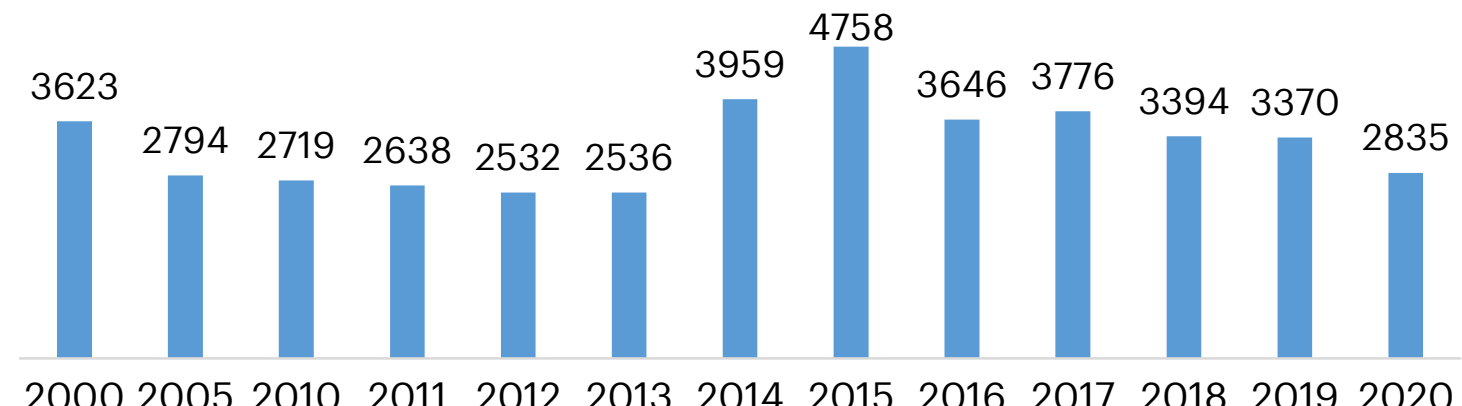

Рис. 2. Вартість угод злиття у світі, трлн дол. США

Джерело: побудовано авторами за матеріалами [16; 17]

Згідно рейтингу Інституту злиттів, поглинань та альянсів (IMAA) [16; 17], найбільшими угодами на світовому ринку злиття стали такі, як: купівля Vodafone AirTouch PLC - Mannesmann AG (вартість 202,7 трлн дол. США) та America Online Inc /Time Warner (вартість 164,7 млн дол. США) (табл. 1).

Таблиця 1

Найбільші угоди на ринку злиття у світі

\begin{tabular}{|l|l|l|l|l|l|}
\hline № & Рік & Назва покупця & Назва цілі & $\begin{array}{l}\text { Вартість, } \\
\text { трлн дол }\end{array}$ & $\begin{array}{l}\text { Вартість, } \\
\text { трлн } \\
\text { євро }\end{array}$ \\
\hline 1 & 1999 & VodafoneAirTouchPLC & MannesmannAG & 202,7 & 204,7 \\
\hline 2 & 2000 & America Online Inc & Time Warner & 164,7 & 160,7 \\
\hline 3 & 2015 & $\begin{array}{l}\text { Verizon } \\
\text { Communications Inc }\end{array}$ & Verizon Wireless Inc & 130,2 & 100,5 \\
\hline 4 & 2007 & Shareholders (Spin out) & Philip Morris Intl Inc & 107,6 & 68,1 \\
\hline
\end{tabular}


Продовження табл. 1

\begin{tabular}{|l|l|l|l|l|l|}
\hline 5 & 2015 & $\begin{array}{l}\text { Anheuser-Busch Inbev } \\
\text { SA/NV }\end{array}$ & SABMiller PLC & 101,5 & 92,3 \\
\hline 6 & 2007 & RFS Holdings BV & $\begin{array}{l}\text { ABN-AMRO Holding } \\
\text { NV }\end{array}$ & 98,2 & 71,3 \\
\hline 7 & 1999 & Pfizer Inc & Warner-Lambert Co & 89,6 & 85,3 \\
\hline 8 & 2017 & Walt Disney Co & 21st Century Fox Inc & 84,2 & 72,5 \\
\hline 9 & 2016 & AT\&T Inc & Time Warner Inc & 79,4 & 72,9 \\
\hline 10 & 2019 & Bristol-Myers Squibb Co & Celgene Corp & 79,4 & 69,7 \\
\hline \multicolumn{7}{|l}{ Джерело: сформовано за даними [16; 17$]$}
\end{tabular}

Дослідження динаміки транзакцій дозволило констатувати, що особливістю сучасного етапу розвитку світового ринку злиття залишається домінування у цих процесах країн Північної Америки та Європи. Найменша кількість угод характерна для Близького Сходу та Північної Африки (рис. 3). Однак підкреслимо, що загальна тенденція падіння зберігається у всіх регіонах, окрім Північної Америки.
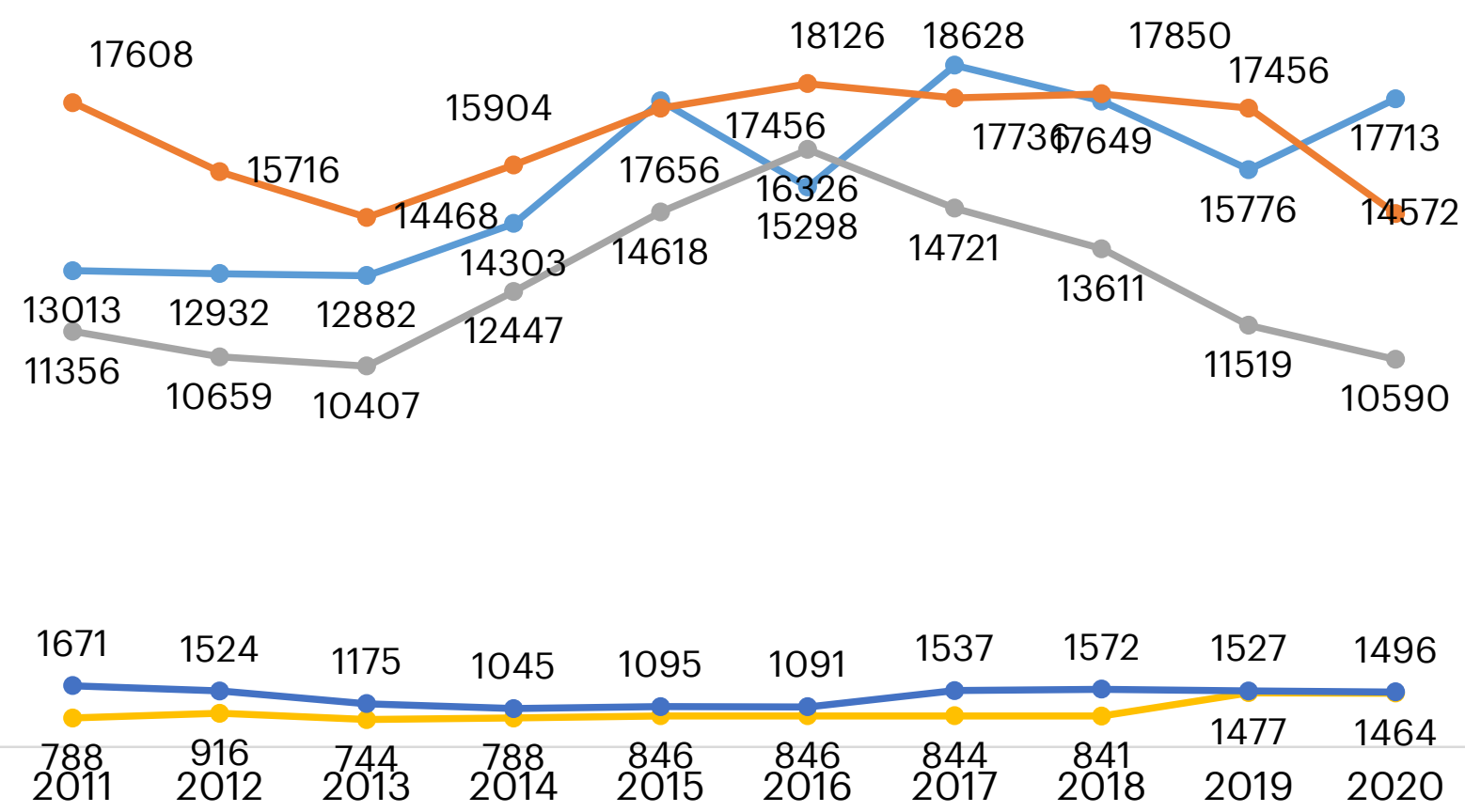

$$
\begin{aligned}
& \text { - Північна Америка } \\
& \text { - Європа } \\
& \text { - Країни Азіатсько-Тихоокеанського регіону } \\
& \text {-Близький Схід та Північна Африка } \\
& - \text { Південна Америка }
\end{aligned}
$$

Рис. 3. Динаміка кількості угод злиття за регіонами світу, одиниць Джерело: побудовано авторами на основі $[16 ; 17 ; 18]$

Акцентуємо увагу на тому, що масштабність процесів злиття на світовому ринку призвела до посилення контролю в цій сфері, який, наприклад, в ЄС здійснюється як регулюючими органами держав, так $\mathrm{i}$ відповідними спільними інституціями, зокрема, Європейською комісією. Такий підхід дозволяє усунути відмінності в національних 
законодавствах і забезпечити єдині транснаціональні правила. При цьому в ряді країн (Нідерланди, Швеція, Ірландія, Греція, Німеччина, Фінляндія, Данія, Австрія), національні законодавчі бар'єри навіть перешкоджають транскордонним злиттям.

Але, разом з цим слід вказати, що саме такі угоди, особливо транскордонні, $\epsilon$ передумовою підвищення конкурентоспроможності економіки ЄС. Тому, однією з задач в цій сфері стало створення ефективного середовища для злиттів і поглинань, що сприятиме не лише формуванню єдиного ринку, а й економічному розвитку країн.

Слід відзначити, що одним із важливих кроків у цьому напрямі стало формування відповідного нормативно-правового базису, який регулює процеси злиття, створюючи спільні правила, зокрема:

Директиви про транскордонні злиття (Cross-border Mergers Directive) у межах єдиного ринку ЄC, яка спрямована на забезпечення єдиних транснаціональних правил та усунення відмінностей в національних законодавствах, що дозволить компаніям-учасникам процесу злиття уникнути неефективних дій (наприклад, вимушеного заснування філіалу у країні цільової компанії задля подальшого поглинання);

Статуту про Європейську компанію, який доповнює вищевказану Директиву та $€$ одним 3 законодавчих інструментів регулювання транскордонних злиттів. Документ розрахований на підприємства, які планують реорганізацію бізнесу в масштабах європейського ринку, та дозволяє компаніям або ї філіалам 3 різних країн $\epsilon C$ об'єднання/злиття як «Societas Europea» (нова юридична форма компанії). Однак, зауважимо, що більшість малих і середніх підприємств, віддають перевагу прямим транскордонним злиттям (уникаючи створення «Європейської компанії»), що пояснюється не зацікавленістю роботи в багатьох країнах ЄC;

Директива про недобросовісну ринкову поведінку (Market Abuse Directive), яка спрямована на запобігання ринковим маніпуляціям через своєчасну подачу керівництвом компаній інформації про купівлю та продаж цінних паперів; Директива про опублікування проспектів (Prospectus Directive), яка передбачає надання компаніями, що беруть участь у злиттях, проспектів 3 інформацією, яка надає можливість інвесторам оцінити її фінансовий стан; Директива про прозорість (Transparency Directive) - вимагає вчасне представлення підприємствами-учасниками щоквартальних, піврічних та річних звітів про фінансовий стан.

Зазначимо, що злиття здатне спричинити ряд ефектів, які залежать від його виду. В цьому контексті представляють інтерес світові практики їх оцінки та формування заходів, спрямованих на запобігання концентраціям та захист економічної конкуренції.

Вважається, що горизонтальні злиття, як і угоди, через усунення 3 ринку реальних або потенційних конкурентів, здатні 3 більшою вірогідністю зашкодити конкуренції.

Тому, в європейській практиці, задля оцінки односторонніх ефектів від такого злиття, використовуються наступні підходи:

визначення коефіцієнту відхилення між двома конкуруючими підприємствами, який вимірює відсоток втрачених продажів (після підвищення цін однією 3 фірм), який отримає інша конкуруюча компанія. Показники розглядаються як міра близькості між організаціями. Високе значення свідчить, що їх товари є близькими замінниками, а злиття спричинить значні односторонні наслідки; 
моделювання злиття - використовує стандартні економічні інструменти для порівняння прогнозованої ціни до та після запропонованої угоди. Якщо прогнозована ціна після злиття значно вища початкової, то таке злиття здатне зашкодити конкуренції;

індекс валового цінового зростання (GUPPI) або тест на підвищення ціни - дозволяє надати кількісну оцінку стимулу компанії після злиття до підвищення ціни [10; 13].

Дещо інші проблеми характерні для скоординованих ефектів. Вони проявляються в результаті горизонтального злиття через полегшення координації своєї поведінки компаніями, які залишаються на ринку та здатні призвести до зменшення конкуренції Дослідження досвіду різних країн світу дозволяє констатувати, що такі ефекти часто спостерігаються в країнах з перехідною економікою, коли нещодавно приватизовані компанії не пристосувались до конкурентного середовища і шукають способи повернутися до більш звичних домовленостей про співпрацю. При цьому ці антиконкурентні угоди $є$ характерними для сфер 3 однорідною продукцією, невеликими обсягами реалізації та однаковим рівнем витрат.

Світові практики доводять, що особливим випадком горизонтального злиття, який може викликати занепокоєння антимонопольних органів, $\epsilon$ об'єднання сторін, які вважаються потенційними, а не фактичними конкурентами. Це пояснюється складністю оцінки намірів компанії, яка ще не працює на ринку. Тому, задача антимонопольних органів у такому випадку - вивчення документації суб'єктів, які підтримують ринкову конкуренцію.

Досвід показує, що втрата потенційної конкуренції, ймовірно, буде викликати найбільше занепокоєння, коли домінуючу вітчизняну компанію купує велика багатонаціональна компанія - виробник того ж продукту. Слід звернути увагу на те, що у випадку, коли після такого злиття залишаться інші значні потенційні учасники ринку, втрата потенційної конкуренції навряд чи буде суттєва.

Враховуючи важливість дослідження вищевказаних ефектів, практичний інтерес представляє організація аналізу угод злиття стосовно впливу на рівень конкуренції.

В цьому контексті вважаємо доцільним розглянути досвід США, де Антимонопольним підрозділом міністерства юстиції і Федеральною торговою комісією розроблено «Положення про горизонтальні злиття», в якому описано основні етапи та інструменти (табл. 1). Як свідчать результати досліджень, саме перші два етапи є основними при прийнятті антимонопольними органами рішення щодо оскарження злиття, а судами - вердикту про його підтримку.

Висновки, отримані за результатами дослідження ситуації на світовому ринку вертикального злиття, дозволяють звернути увагу на достатню ефективність таких процесів як для підприємств, так і для споживачів через мотивацію підвищення якості продукції, можливість виходу нових компаній на ринок тощо. Проте, необхідно зауважити, що за певних умов (наприклад, ускладнення входу на ринок через додаткові бар'єри: слабо розвинені відносини на ринках капіталу, землі тощо) вертикальні злиття можуть негативно впливати на рівень конкуренції, що частіше спостерігається в країнах 3 перехідною економікою, або в тих, які розвиваються. 
Етапи аналізу угод злиття в США

\begin{tabular}{|c|c|c|}
\hline Етапи & Особливості етапу & Інструменти \\
\hline $\begin{array}{l}\text { Визначення (i } \\
\text { опис) ринку }\end{array}$ & 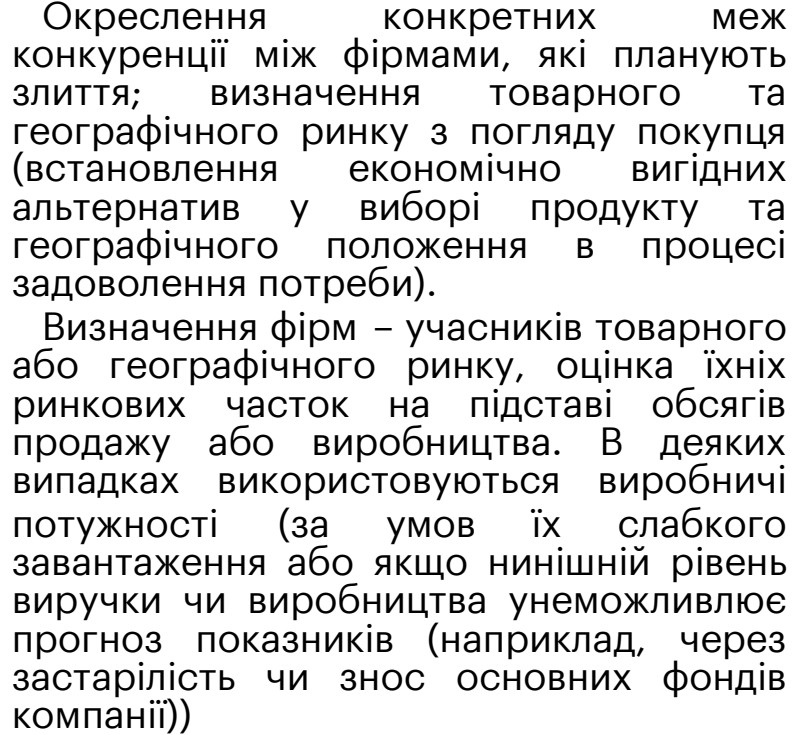 & $\begin{array}{l}\text { Визначення } \\
\text { перехресної цінової } \\
\text { еластичності } \\
\text { альтернативних } \\
\text { товарів; аналіз обсягів } \\
\text { закупівель і цін в } \\
\text { магазинах; учасників } \\
\text { опитування учаснике } \\
\text { ринку, } \\
\text { документів компаній, } \\
\text { «польові» } \\
\text { експерименти; } \\
\text { Індекс Херфіндаля- } \\
\text { Хіршмана; частка } \\
\text { чотирьох найбільших } \\
\text { фірм у сумарному } \\
\text { показнику галузі } \\
\text { та/або інші показники } \\
\text { концентрації ринку }\end{array}$ \\
\hline $\begin{array}{lr}\text { Оцінка } & \\
\text { бар'єрів } & \text { для } \\
\text { виходу } & \text { на } \\
\text { ринок } & \end{array}$ & 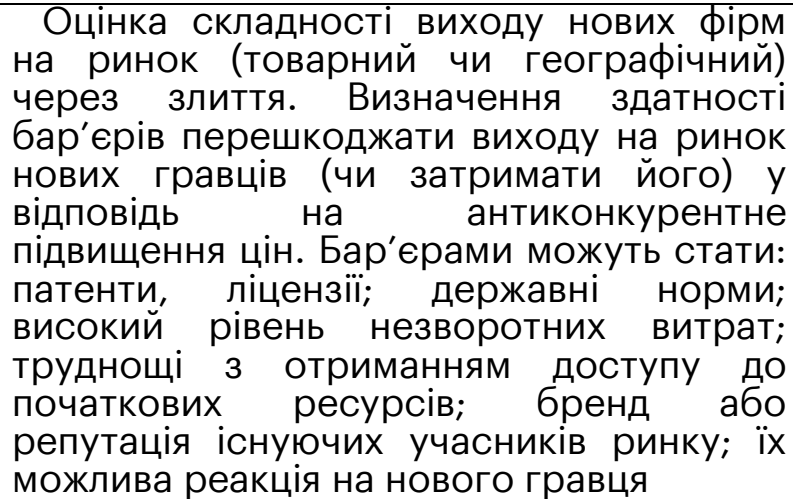 & $\begin{array}{l}\text { Якщо після злиття } \\
\text { вихід на ринок нових } \\
\text { гравців оцінюється як } \\
\text { «своєчасний, } \\
\text { імовірний } \\
\text { масштабний», то } \\
\text { злиття можна не } \\
\text { оскаржувати навіть у } \\
\text { тому випадку, якщо } \\
\text { воно призведе до } \\
\text { високої концентрації } \\
\text { ринку }\end{array}$ \\
\hline $\begin{array}{l}\text { Виявлення } \\
\text { потенційних } \\
\text { негативних } \\
\text { наслідків } \\
\text { злиття дляя } \\
\text { конкуренції }\end{array}$ & $\begin{array}{l}\text { Здійснюється за такими видами } \\
\text { негативного впливу злиття на } \\
\text { конкуренцію: } \\
\text { «ефект координації» - ймовірність } \\
\text { того, що через зменшення кількості } \\
\text { гравців на рину, угода полегшить } \\
\text { координацію дій конкурентів, які } \\
\text { залишилися, що призведе до скорочення } \\
\text { виробництва; } \\
\text { "ефект односторонніх дій» - } \\
\text { передбачає, що об'єднана фірма може, } \\
\text { наприклад, підняти ціну й тим самим } \\
\text { погіршити становище покупців, а інші } \\
\text { компанії будуть конкурувати в цьому } \\
\text { новому вимірі. }\end{array}$ & $\begin{array}{lr}\text { Економетрична оцінка } \\
\text { попиту; порівняння } \\
\text { цін; аналіз торгових } \\
\text { потоків; } \\
\text { кореляції аналіз } \\
\text { (еластичності } \quad \text { цін); } \\
\text { SSNIP-тест (тест на } \\
\text { визначення r } \\
\text { гіпотетичного } \\
\text { монополіста) }\end{array}$ \\
\hline $\begin{array}{l}\text { Розрахунок } \\
\text { ефективності } \\
\text { злиття }\end{array}$ & $\begin{array}{l}\text { Трактується органами з контролю за } \\
\text { злиттями різної юрисдикції неоднаково. } \\
\text { Так, апеляційними судами США } \\
\text { порівняння рувня } 9 \text { підвищення } \\
\text { ефективності зі збитком приймається як } \\
\text { аргумент конкуренції після злиття, а } \\
\text { Верховним судом - ні. у внутрішніх } \\
\text { документах антимонопольного органу } \\
\text { ефективність враховується при прийнтті } \\
\text { рішення щодо доцільності оскарження } \\
\text { злиття }\end{array}$ & $\begin{array}{l}\text { Ефект вимірюється на } \\
\text { основі «стандарту } \\
\text { добробуту } \\
\text { споживачів». } \\
\text { Визначається чи } \\
\text { підвищиться добробут, } \\
\text { наприклад, завдяки } \\
\text { скороченню витрат; чи } \\
\text { знизиться - через } \\
\text { ослаблення } \\
\text { конкуренції }\end{array}$ \\
\hline
\end{tabular}


Аналіз світових практик розгляду вертикальних угод дозволив констатувати, що в порівнянні з горизонтальним злиттям, ефекти за їх результатами визначати набагато складніше, що пояснюється відсутністю змін ринкової частки. Крім того, антиконкурентні ефекти $є$ непрямими та виникають внаслідок зміни стимулів або обмежень, призводячи до зниження добробуту споживачів, зменшення ефективності, обмеження конкурентів чи змов на ринку.

Акцентуємо увагу на тому, що антимонопольні органи держави можуть виступати проти вертикальних злиттів, якщо переконані, що такі угоди здатні призвести до домінуючого становища суб'єкту господарювання. При цьому серед найважливіших умов, необхідних для оскарження такого злиття на цих підставах слід відзначити:

- домінуюче місце на ринку однієї зі сторін;

- збільшення бар'єрів для входження на ринок через контроль над вертикально пов'язаним ринком з боку домінуючої компанії.

Зазначимо, що практичний інтерес представляє нормативноправове підґрунтя таких процесів, основу якого складають керівництва по вертикальних злиттях, що діють в більшості розвинених країн світу.

Так, в США діє Керівництво по негоризонтальному злиттю (прийнято Міністерством юстиції у 1984 р.), яким визначено основні умови оскарження Департаментом таких угод. А саме:

1. Вертикальне злиття посилює бар'єри входження на ринок як на висхідному, так і на низхідному ринку, що спричиняє антиконкурентні ефекти у випадку збігу наступних умов:

ступінь інтеграції, яка виникає після угоди, повинна бути досить великою, щоб входження на первинний ринок (відносно якого розглядаються антиконкурентні ефекти), вимагало 6 входження і на вторинний ринок;

- додаткова вимога для входження на вторинний ринок має ускладнити вихід на первинний ринок новим фірмам;

- збільшення вхідних бар'єрів на первинному ринку, ймовірно, негативно вплине на ефективність діяльності суб'єктів даного ринку.

2. Вертикальне злиття робить координацію більш легкою та ефективною через спрощення моніторингу цін на висхідному ринку.

3. Угода забезпечує в результаті можливості об'єднаній компанії уникати ефективного моніторингу цін [11].

Однак, якщо у перших двох випадках значення індексу Херфіндаля-Хіршмана менш ніж 1800 на первинному ринку і проблеми конкуренції $€$ малоймовірними, то існує можливість отримання дозволу на підписання угоди.

Представляють інтерес і Керівні принципи, які прийняті Бюро 3 конкуренції при проведенні злиттів Канади (2004р.). Зазначимо, що вони базуються на теорії справ, яка передбачає потенційний антиконкурентний вплив від вертикального злиття. По аналогії 3 відповідним документом, прийнятим у США, він базується на наступних теоріях:

1. Збільшення бар'єрів, яке обумовлюється двоетапним входженням на ринок.

2. Потенціал угоди сприятиме координації шляхом підвищення прозорості як на висхідному, так і на низхідному ринках. 
у Великобританії питання вертикального злиття знаходиться в полі зору такого документу, як «Основні рекомендації з оцінки злиттів» (набув чинності 32003 р.). Відзначаючи, що вертикальні злиття сприяють підвищенню ефективності, але можуть впливати на конкуренцію. Управління справедливої торгівлі практикує застосування обмежень та координації.

Слід зазначити, що прийняття «Керівництва по негоризонтальним злиттям» стало складовою реформ в сфері контролю над такими процесами в країнах ЄС. Відповідно до цього документу визначаються наступні можливі вертикальні ефекти:

1. Неузгоджені ефекти, які включають:

обмеження - за яких в результаті злиття утруднюється або виключається доступ фактичних або потенційних конкурентів до поставок або ринків, що знижує здатність компаній до конкуренції;

інші неузгоджені ефекти - ризик доступу вертикально інтегрованої компанії до комерційно важливої інформації стосовно діяльності конкурентів на висхідному та низхідному ринках

2. Узгоджені ефекти, які знаходять прояв у скоординованій поведінці суб'єктів господарювання, підвищенні рівня прозорості ринку, полегшення взаємодії між іншими учасниками ринку.

Зауважимо, що завдяки даному документу, підходи Комісії до розгляду Справ про вертикальне злиття зазнали значних змін. Аналіз таких Справ в різних галузях економіки, де злиття призводило до ризику обмеження ключового компонента або сировини (які контролювала об'єднана компанія) для конкурентів на низхідних ринках, дозволив констатувати різноманітність висновків Комісії. Проте, за більшістю з них, Комісією було винесено позитивне рішення про дозвіл через те, що ймовірність виникнення ускладнень для ефективної конкуренції не були доведені в достатній мірі (наприклад, Справа «Philips»/ «Intermagnetics and Thales»). За деякими Справами дозвіл на злиття надавався за умов здійснення компаніями запобіжних заходів, які Комісія визнавала задовільними для усунення сумнівів щодо конкурентності злиття (наприклад, Справи «Johnson \& Johnson / Pfizer Consumer Healthcare»; «Evraz/ Highveld»).

Слід також звернути увагу, що більшість Справ, в яких аналізувались можливі вертикальні ефекти, розглядались Комісією на першому етапі. А більш глибоке дослідження здійснювалось за умов виявлення, в процесі розслідування на цій фазі, серйозних ризиків обмеження конкуренції в результаті злиття та неефективності засобів правового захисту, запропонованих сторонами, для усунення ймовірних порушень у повній мірі. Але, констатуємо, що кількість таких додаткових досліджень по вертикальних угодах $\epsilon$ невеликою (наприклад, Справа «Thales»).

Висновки і перспективи подальших досліджень. Таким чином, попри зменшення кількості угод, світовий ринок злиття характеризується масштабністю процесів, які, наряду з додатковими можливостями для розвитку бізнесу, здатні завдати певні загрози для конкурентного середовища внаслідок ринкової концентрації. Характерною особливістю розвитку сучасного світового ринку злиття залишається домінуючим у цих процесах країн Північної Америки та Європи. Значна кількість таких угод призвела до посилення контролю в цій сфері з боку національних регулюючих органів (в країнах $\epsilon$ і відповідних спільних інституцій). А одним із важливих кроків у цьому 
напрямі стало формування відповідної нормативно-правової бази, яка регулює процеси злиття.

Зважаючи на можливі негативні наслідки злиття, антимонопольними органами розвинених країн напрацьовано певний досвід організації процедур їх аналізу та дослідження впливу на рівень конкуренції, а також сформовано специфічні підходи для оцінки антиконкурентних ефектів, які можуть виникати в процесі реалізації горизонтальних та вертикальних угод. Такі практики представляють інтерес і для України, оскільки дозволяють уникнути ймовірних змов та антиконкурентної поведінки. Однак, запровадження таких методів, підходів та інструментів потребує формування відповідного нормативного базису, що складає перспективи подальших досліджень.

Література:

1. Фролова Т.О. Глобалізаційні тенденції розвитку процесів злиття та поглинання у світовій економіці. Економічна наука. Інвестиції: практика та досвід. 2014. № 18. С. 29-35.

2. Farrell J., Shapiro C. Antitrust Evaluation of Horizontal Mergers: An Economic Alternative to Market Definition. The B.E. Journal of Theoretical. Economics Policies and Perspectives. 2010. Vol. 10, Issue 1. URL: https://faculty.haas.berkeley.edu/shapiro/alternative.pdf.

3. Гамма Т. М. Особливості та перспективи розвитку M\&A в Україні. Науковий вісник Мукачівського державного університету. 2016. Вип. 1 (15). С. 106-112.

4. Єгорова Г.А. Компаративний аналіз методик оцінювання ефективності злиттів та поглинань: світовий та вітчизняний досвід. Інвестиції: практика та досвід. 2016. № 21. С. 74-79.

5. Kengelbach J., Utzerath D., Kaserer C., Schatt S. Divide and Conquer. How Successful M\&A Deals Split the Synergies. The Boston Consulting Group. 2013, 14 p.

6. Мелещенко А.І., Цимбал Ю.В. Сучасні тенденції функціонування та розвитку транснаціональних корпорацій і їх вплив на світову економіку в умовах глобалізації. Інвестиції: практика та досвід. 2016. № 1. С. 19-24.

7. Побоченко Л. М. Регіональний розподіл світового ринку процесів М\&А. Стратегія розвитку України. 2017. № 1. С. 70-78.

8. Пучко І. В. Тенденції та пріоритети розвитку злиттів і поглинань в умовах інституційних трансформацій. Глобальні та національні проблеми економіки. 2015. №3. С. 769-773.

9. Сабадаш В. В., Гонтар Д. А. Ринки злиттів і поглинань: стан, проблеми функціонування і тенденції розвитку. Механізм регулювання економіки. 2015. № 4. С. 127-138.

10. Стахєєва Г. О. Контроль за концентраціями між суб'єктами господарювання в системі антимонопольного права Європейського Союзу: монографія. Одеса: Фенікс, 2014. 224 с.

11. Hart-Scott-Rodino Annual Report (Fiscal Year 2017). Federal Trade Commission. URL: https://www.ftc.gov/system/files/documents/r eports/federal-trade-commission-bureau-competitiondepartmentjustice-antitrust-division-hart-scott-rodino/ p110014_fy_2017_hsr_report_final_april_2018.pdf.

12. Horizontal Merger Guidelines of the United States Department of Justice and the Federal Trade Commission. URL: https://www.ftc.gov/ publicstatements/2010/08/horizontal-merger-guidelinesunited-statesdepartment-justice-federal. 
13. Merger control producers. European Commission. URL: https://ec.europa.eu/competition/elojade/isef/index.cfm?clear=1\&policy area $i d=2$.

14. Про затвердження «Положення про порядок подання заяв до Антимонопольного комітету України про попереднє отримання дозволу на концентрацію суб'єктів господарювання» (Положення про концентрацію): Розпорядження АМКУ від 19 лют. 2002 р. № 33-p. URL: https://zakon.rada.gov.ua/laws/show/z0284-02\#Text.

15. Про надання рекомендаційних роз'яснень щодо порядку застосування частини першої статті 25 Закону України "Про захист економічної конкуренції" (щодо оцінки горизонтальних концентрацій): Рекомендаційні роз'яснення АMKУ від 27 груд 2016 № 49-pp URL: https://zakon. rada.gov.ua/ rada/show/v49pp226-16\#Text.

16. Imaa-institute. M\&A Statistics. URL: https://imaainstitute.org/mergers-and-acquisitions-

statistics/?fbclid=IwAR21aSellz4zsaCKaS2aI9wtzdSIYfjurIEiQpOuKb7taM Fq9VWx U29rdc.

17. Institute for Mergers, Acquisitions and Alliances. URL: www.imaainstitute.org.

18. UNCTAD. URL: http://stats.unctad.org.

References:

1. Frolova T. O. Ghlobalizacijni tendenciji rozvytku procesiv zlyttja ta poghlynannja u svitovij ekonomici. Ekonomichna nauka. Investyciji: praktyka ta dosvid. 2014. \# 18. S. 29-35.

2. Farrell J., Shapiro C. Antitrust Evaluation of Horizontal Mergers: An Economic Alternative to Market Definition. The B.E. Journal of Theoretical. Economics Policies and Perspectives. 2010. Vol. 10, Issue 1. URL: https://faculty.haas.berkeley.edu/shapiro/alternative.pdf.

3. Ghamma T. M. Osoblyvosti ta perspektyvy rozvytku M\&A v Ukrajini. Naukovyj visnyk Mukachivsjkogho derzhavnogho universytetu. 2016. Vyp. 1 (15). S. 106-112.

4. Jeghorova Gh. A. Komparatyvnyj analiz metodyk ocinjuvannja efektyvnosti zlyttiv ta poghlynanj: svitovyj ta vitchyznjanyj dosvid. Investyciji: praktyka ta dosvid. 2016. \# 21. S. 74-79.

5. Kengelbach J., Utzerath D., Kaserer C., Schatt S. Divide and Conquer. How Successful M\&A Deals Split the Synergies. The Boston Consulting Group. 2013, 14 p.

6. Meleshhenko A. I., Cymbal Ju. V. Suchasni tendenciji funkcionuvannja ta rozvytku transnacionaljnykh korporacij i jikh vplyv na svitovu ekonomiku $v$ umovakh ghlobalizaciji. Investyciji: praktyka ta dosvid. 2016. \# 1. S. 19-24.

7. Pobochenko L. M. Reghionaljnyj rozpodil svitovogho rynku procesiv M\&A. Strateghija rozvytku Ukrajiny. 2017. \# 1. S. 70-78.

8. Puchko I.V. Tendenciji ta priorytety rozvytku zlyttiv i poghlynanj $v$ umovakh instytucijnykh transformacij. Ghlobaljni ta nacionaljni problemy ekonomiky. 2015. \#3. S. 769-773.

9. Sabadash V. V., Ghontar D. A. Rynky zlyttiv i poghlynanj: stan, problemy funkcionuvannja i tendenciji rozvytku. Mekhanizm reghuljuvannja ekonomiky. 2015. \# 4. S. 127-138.

10. Stakhjejeva Gh. O. Kontrolj za koncentracijamy mizh sub'jektamy ghospodarjuvannja $\mathrm{v}$ systemi antymonopoljnogho prava Jevropejsjkogho Sojuzu: monoghrafija. Odesa: Feniks, 2014. 224 s. 
11. Hart-Scott-Rodino Annual Report (Fiscal Year 2017). Federal Trade Commission. URL: https://www.ftc.gov/system/files/documents/r eports/ federal-trade-commission-bureau-competitiondepartmentjustice-antitrust-division-hart-scott-rodino/ p110014_fy_2017_hsr_report_final_april_2018.pdf.

12. Horizontal Merger Guidelines of the United States Department of Justice and the Federal Trade Commission. URL: https://www.ftc.gov/ publicstatements/2010/08/horizontal-mergerguidelinesunited-states-department-justice-federal.

13. Merger control producers. European Commission. URL: https://ec.europa.eu/competition/elojade/isef/index.cfm?clear=1\&policy _area_id=2.

14. Pro zatverdzhennja «Polozhennja pro porjadok podannja zajav do Antymonopoljnogho komitetu Ukrajiny pro poperednje otrymannja dozvolu na koncentraciju sub'jektiv ghospodarjuvannja» (Polozhennja pro koncentraciju): Rozporjadzhennja AMKU vid 19 ljut. 2002 r. \# 33-r. URL: https://zakon.rada.gov.ua/laws/show/zO28402\#Text.

15. Pro nadannja rekomendacijnykh roz'jasnenj shhodo porjadku zastosuvannja chastyny pershoji statti 25 Zakonu Ukrajiny "Pro zakhyst ekonomichnoji konkurenciji" (shhodo ocinky ghoryzontaljnykh koncentracij): Rekomendacijni roz'jasnennja AMKU vid 27 ghrud 2016 \# 49-rr URL: https://zakon. rada.gov.ua/ rada/show/v49pp226-16\#Text.

16. Imaa-institute. M\&A Statistics. URL: https://imaainstitute.org/mergers-and-acquisitions-

statistics/?fbclid=IwAR21qSellz4zsaCKqS2al9wtzdSIYfjurlEi QpOuKb 7taMFq9VWx_U29rdc.

17. Institute for Mergers, Acquisitions and Alliances. URL: www.imaainstitute.org.

18. UNCTAD. URL: http://stats.unctad.org.

The purpose of the article is to study the current trends in the global market of mergers and the experience of developed countries in the field of protection of economic competition as a result of such agreements.

The role of integration agreements in international business is determined. It is established that, on the one hand, they act as an effective mechanism for the development of companies, and on the other - lead to the monopolization of markets.

Current trends in the global merger market are analyzed. Emphasizing the scale of such agreements, a decrease in their number was noted. So, since 2000, more than 790 thousand transactions worth more than 57 trillion dollars USA have been announced worldwide. However, reaching its maximum in the last two decades, starting in 2017, the number of merger agreements began to decline.

It is established that the peculiarity of the modern world merger market is the dominance of these countries in North America and Europe. The smallest number of agreements is typical for the Middle East and North Africa.

Emphasis is placed on strengthening control in this area by national regulators (in EU countries and joint regulatory institutions). One of the important steps in this direction was the formation of an 
appropriate regulatory framework governing mergers.

The content of horizontal and vertical effects that may arise in the process of implementation of merger agreements is considered and attention is focused on their possible anti-competitive effects. The practices introduced in developed countries in the field of development of fair competition and prevention of excessive concentration of markets are studied. Based on the study of the Horizontal and Vertical Merger Cases, attention is drawn to the possible impact of anticompetitive effects (both agreed and uncoordinated).

It is noted that the anti-monopoly authorities of developed countries have gained some experience in organizing procedures for analyzing merger agreements and studying their impact on the level of competition, formed specific approaches to assess anticompetitive effects that may occur in the implementation of horizontal and vertical agreements. Such practices are also of interest to Ukraine, as they avoid possible conspiracies and anti-competitive behavior.

УДК 330.341.1

DOI: $10.35340 / 2308-104 X .2021 .91-2-02$

\section{CLASSIFICATION OF TYPES OF INNOVATIONS AND METHODS OF THEIR DEVELOPMENT AND DISTRIBUTION}

\author{
ABESADZE R., \\ Doctor of Science in Economics, \\ Professor, Director of Institute, \\ BURDULI V., \\ Doctor of Science in Economics, \\ Professor, Head of Department of \\ Sectoral and Regional Economics, \\ LAZARASHVILI T. \\ Deputy Director of the Institute \\ P. Gugushvili Institute of \\ Economics of I. Javakhishvili TSU \\ (Tbilisi, Georgia)
}

\section{КЛАСИФІКАЦІЯ ВИДІВ ІННОВАЦІЙ I МЕТОДІВ ЇХ РОЗРОБКИ ТА РОЗПОВСЮДЖЕННЯ}

\author{
АБЕСАДЗЕ Р. Б., \\ Доктор економічних наук, \\ професор, директор інституту, \\ БУРДУЛІ В. Ш., \\ доктор економічних наук, \\ професор, завідувач кафедри \\ галузевої та регіональної \\ економіки, \\ ЛАЗАРАШВІЛІ Т. Н., \\ заступник директора інституту
} П. Гугушвілі Інститут економіки ТДУ ім. І. Джавахішвілі (Тбілісі, Грузія)

У роботі класифікуються види інновацій та систематизуються шляхи їх розвитку та розповсюдження. Види інновацій класифікуються в контексті критеріїв значущості, ступеня новизни, предмета та обсягу, за розробником, за типом інновації, за місцем у системі підприємства та іншими критеріями, а потім детально описуються. Систематизуються та пояснюються методи розробки та інструменти розповсюдження інновацій.

Ключові слова: види інновацій, основні, удосконалюючі та псевдоінновації, інновації на виробництві, технологічні інновації, методи розробки інновацій, інструменти розповсюдження інновацій.

В работе классифицируются виды инноваций и систематизируются способы их разработки и распространения. Типы инноваций классифицируются в контексте критериев значимости, 